\title{
Secondary prevention- an essential component of the comprehensive rehabilitation of patients with heart failure
}

Pop Dana ${ }^{1}$, Caloian Bogdan ${ }^{1}$, Cismaru Gabriel ${ }^{1}$, Guşetu Gabriel ${ }^{1}$, Roşu Radu ${ }^{1}$, Comşa Horaţiu ${ }^{1}$, Zdrenghea Dumitru Tudor ${ }^{1}$

1.Cardiology - Rehabilitation Department, “Iuliu Hatieganu” University of Medicine and Pharmacy, Cluj-Napoca

E-mail address: bogdan912@yahoo.com

\begin{abstract}
Heart failure is currently a real public health problem due to the extremely high morbidity and mortality of this disease. In this context, cardiovascular prevention measures should be implemented as early as possible. In addition to classic prevention measures, a number of extremely important specific recommendations should be considered: informing patients about their underlying disease, identifying the cardiovascular and non-cardiovascular factors that have led to cardiac decompensation, reducing daily salt consumption, monitoring body weight, forbidding smoking and recreational substances, conducting a regular exercise program under supervision, and increasing adherence to treatment.
\end{abstract}

Key words: heart failure, cardiovascular prevention,

Heart failure is currently a real public health problem due to its extremely high morbidity and mortality despite the complex and comprehensive treatments of this disease [1]. About $4.7 \%$ of the general population in Romania suffers from heart failure [2]. An analysis by sex shows that in a study published in 2013 and carried out at the Rehabilitation Hospital, the Cardiology Department Cluj-Napoca, heart failure females were generally older than males [3].

The presence of co-morbidities such as arterial hypertension, diabetes mellitus, atrial fibrillation, ischemic heart disease induces an aggravation of this disorder. In a study on patients with heart failure conducted at the Rehabilitation Hospital, the Cardiology Department Cluj-Napoca, Romania, the prevalence of atrial fibrillation was $48.3 \%$ and that of diabetes mellitus $30.8 \%$ [4]. In general, one of the most frequent causes of heart failure in Europe is ischemic heart disease, which is also the case in Romania [3]. There is also a high rate of hypertensive patients with heart failure, the incidence of high blood pressure displaying a constant increase in Romania (40.41\%) [5].

Thus, with every acute event, myocardial injury may contribute to progressive left ventricular dysfunction [6,7].

In this context, cardiovascular prevention measures should be implemented as early as possible. In addition to classic prevention methods, a number of extremely important specific recommendations should be considered $[1,8]$.

- Informing patients about their underlying disease. Providing details about precipitating factors (respiratory intercurrences, anemia, hyperthyroidism, etc.) for the development of heart failure. Knowing the first symptoms and signs of heart failure for an early presentation to specialized medical services.

- Identifying the cardiovascular or noncardiovascular factors that have led to cardiac decompensation.

- Performing mandatory paraclinical examinations: electrocardiogram, pulmonary Xray, echocardiography, natriuretic hormones, blood count, serum electrolytes, creatinine, urea, Creactive protein, uric acid, glycated hemoglobin, lipid fractions, TSH, ferritin, transferrin saturation, for evaluation, prognosis and treatment.

- Patients with heart failure should monitor their weight daily. In case of a weight gain of more than $2 \mathrm{~kg}$ in 3 days accompanied by dyspnea and lower limb edema, they will be advised to increase the dose of diuretics and/or to visit the doctor urgently. Diet should respect the basic principles regarding the consumption of salt, fluids, alcohol, etc.

- Obesity. The presence of cachexia in heart failure is associated with a negative prognosis.

Theoretically, obesity is a risk factor for heart failure, inducing dyspnea and a decrease of the exercise capacity. However, the presence of obesity 
is associated with a low mortality rate in heart failure, which is why patients with a moderate degree of obesity (BMI $<35 \mathrm{~kg} / \mathrm{m}^{2}$ ) will not be recommended to lose weight. Nevertheless, this is mandatory in the presence of a BMI of $35-45 \mathrm{~kg} / \mathrm{m}^{2}$.

- Smoking and recreational substances. Forbidding smoking is the best cost-effective strategy for the prevention of cardiovascular diseases. All patients with heart failure will be encouraged and stimulated by non-pharmacological and pharmacological measures to quit smoking. Recreational substance use is also forbidden.

- Psychosocial factors. All patients with heart failure should be investigated for the presence of psychosocial factors that may aggravate the disease: a precarious social status, stress at the workplace and in family life, anxiety and particularly depression. The presence of depression contributes to an aggravation of the disease by a decrease of compliance and adherence to treatment. This is why these patients should benefit whenever necessary from family support, as well as from specialized psychological support.

- Physical activity. Before recommending a certain type of physical activity for patients with heart failure, their exercise capacity should be evaluated. A physical activity program will include aerobic exercises in particular, as well as exercises for the improvement of breathing. All these should be performed on a regular basis.

- Leisure activities. During leisure activities, patients will be advised to strictly take the prescribed medication, to monitor and adapt their fluid intake (particularly during flights or in hot climate regions). Sun exposure may favor the development of skin reactions in patients on amiodarone treatment. Exposure to very high altitudes may have negative effects on oxygenation. Patients with ICDs should provide information about these when travelling by air.

- Sleep and breathing. Problems related to breathing difficulties during sleep should be identified by both patients and doctors (administration of diuretics, salt intake, presence of obesity, alcohol consumption, smoking).
- Vaccinations. Because respiratory disorders are among the most frequent causes of cardiac decompensation, it is recommended that patients with heart failure should be vaccinated against influenza and pneumococcus.

- Use of contraceptives. Premenopausal women with heart failure NYHA III-IV can be advised to take third generation contraceptives (progesterone derivatives) with low estrogen content, to avoid pregnancy.

- Adherence to treatment and secondary drug prevention play an essential role in the case of patients with heart failure. As shown before, they should be made aware of the role of each drug in preventing cardiac decompensation. In this respect, they should know how to increase or reduce the dose of diuretics depending on symptoms, the presence of edema, weight gain or loss.

Regarding drugs with cardioprotective effects, these have the following indications: angiotensin converting enzyme inhibitors and beta-blockers are recommended to all asymptomatic patients with left ventricular dysfunction and a history of myocardial infarction for the prevention of heart failure.

Also, these two combined medications will be administered to all symptomatic heart failure patients with reduced ejection fraction for decreasing the number of hospitalizations and mortality risk. If patients remain asymptomatic despite this treatment, they will also have to receive anti-aldosterone treatment. The 2017 ESC Guidelines for the management of acute myocardial infarction in patients presenting with STsegment elevation even discuss the importance of long-term administration of angiotensin converting enzyme inhibitors and beta-blockers to all patients with acute myocardial infarction, regardless of the presence or absence of heart failure [9]. Sartans represent an alternative to angiotensin converting enzyme inhibitors when these are contraindicated or not tolerated by patients. There is strong evidence of their role in decreasing mortality in patients with heart failure [10].

In conclusion, secondary prevention (lifestyle change and drug prevention), along with cardiac rehabilitation, plays an important role in reducing the cardiac morbidity and mortality of patients with heart failure. 


\section{Bibliography}

1. Piepoli MF, Hoes AW, Agewall S, Albus C, Brotons C, Catapano AL, Cooney MT, Corrà U, Cosyns B, Deaton C, Graham I, Hall MS, Hobbs FD, Løchen ML, Löllgen H, Marques-Vidal P, Perk J, Prescott E, Redon J, Richter DJ, Sattar N, Smulders Y, Tiberi M, van der Worp HB, van Dis I, Verschuren WM; Authors/Task Force Members. 2016 European Guidelines on cardiovascular disease prevention in clinical practice: The Sixth Joint Task Force of the European Society of Cardiology and Other Societies on Cardiovascular Disease Prevention in Clinical Practice (constituted by representatives of 10 societies and by invited experts). Developed with the special contribution of the European Association for Cardiovascular Prevention \& Rehabilitation (EACPR). Eur. Heart J. 2016;37:2315-2381.

2. Go AS, Mozaffarian D, Roger VL, Benjamin EJ, Berry JD, Borden WB, Bravata DM, Dai S, Ford ES, Fox CS, Franco S, Fullerton HJ, Gillespie C, Hailpern SM, Heit JA, Howard VJ, Huffman MD, Kissela BM, Kittner SJ, Lackland DT, Lichtman JH, Lisabeth LD, Magid D, Marcus GM, Marelli A, Matchar DB, McGuire DK, Mohler ER, Moy CS, Mussolino ME, Nichol G, Paynter NP, Schreiner PJ, Sorlie PD, Stein J, Turan TN, Virani SS, Wong ND, Woo D, Turner MB; American Heart Association Statistics Committee and Stroke Statistics Subcommittee. Heart disease and stroke statistics-2013 update: a report from the American Heart Association. Circulation. 2013;127(1):e6-e24.

3. Pop D, Penciu OM, Sitar-Taut AV, Zdrenghea DT. Comparative heart failure profile over a 3year period in a Romanian general hospital. Clin Interv Aging. 2013;8:999-1005.

4. Sitar Taut AV, Pop D, Zdrenghea DT. NTproBNP values in elderly heart failure patients with atrial fibrillation and diabetes. J Diabetes Complications. 2015 ;29(8):1119-23.

5. Darabont R, Tautu OF, Pop D, Fruntelata A, Deaconu A, Onciul S, Salaru D, Micoara A, Dorobantu M . Visit-to-Visit Blood Pressure Variability and Arterial Stiffness Independently Predict Cardiovascular Risk
Category in a General Population: Results from the SEPHAR II Study. Hellenic J Cardiol. 2015;56(3):208-16.

6. Gheorghiade M, De Luca L, Fonarow GC, Filippatos G, Metra M, Francis GS. Pathophysiologic targets in the early phase of acute heart failure syndromes. Am J Cardiol. 2005;96(6A):11G-17G.

7. Gheorghiade M, Pang PS. Acute heart failure syndromes. J Am Coll Cardiol 2009;53:55773.

8. Ponikowski P, Voors AA, Anker SD, Bueno H, Cleland JG, Coats AJ, Falk V, GonzálezJuanatey JR, Harjola VP, Jankowska EA, Jessup M, Linde C, Nihoyannopoulos P, Parissis JT, Pieske B, Riley JP, Rosano GM, Ruilope LM, Ruschitzka F, Rutten FH, van der Meer P; Authors/Task Force Members; Document Reviewers. 2016 ESC Guidelines for the diagnosis and treatment of acute and chronic heart failure: The Task Force for the diagnosis and treatment of acute and chronic heart failure of the European Society of Cardiology (ESC). Developed with the special contribution of the Heart Failure Association (HFA) of the ESC. Eur Heart J. 2016; 37: 21292200.

9. Ibanez B, James S, Agewall S, Antunes MJ, Bucciarelli-Ducci C, Bueno H, Caforio ALP, Crea F, Goudevenos JA, Halvorsen S, Hindricks $\quad G$, Kastrati A, Lenzen MJ, Prescott E, Roffi M, Valgimigli M, Varenhorst C, Vranckx P, Widimský P. 2017 ESC Guidelines for the management of acute myocardial infarction in patients presenting with STsegment elevation: The Task Force for the management of acute myocardial infarction in patients presenting with STsegment elevation of the European Society of Cardiology (ESC). Eur Heart J. 2017; doi: 10.1093/eurheartj/ehx393.

10. Sayer G, Bhat G. The renin-angiotensinaldosterone system and heart failure. Cardiol Clin. 2014 ;32(1):21-3 